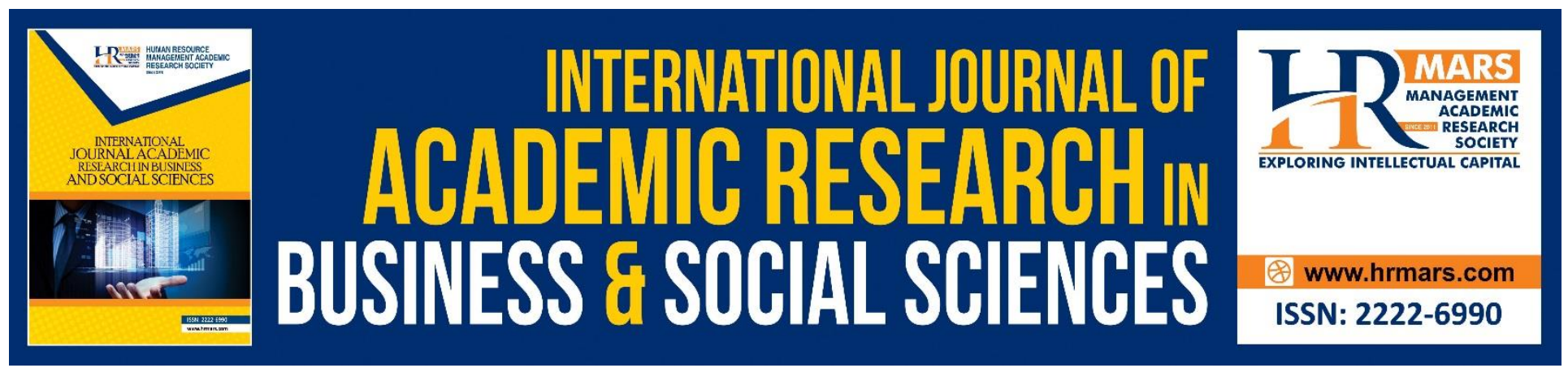

\title{
The Principle of Interaction between Revelation and Mind under Islamic Perspective
}

Aminudin Basir @ Ahmad, Chairozila Mohd Shamsuddin, Azwira Abdul Aziz, Jamsari Alias, Akila Mamat

To Link this Article: http://dx.doi.org/10.6007/IJARBSS/v8-i10/4749

DOI: $10.6007 /$ IJARBSS/v8-i10/4749

Received: 13 Sept 2018, Revised: 23 Oct 2018, Accepted: 29 Oct 2018

Published Online: 31 October 2018

In-Text Citation: (Ahmad, Shamsuddin, Aziz, Alias, \& Mamat, 2018)

To Cite this Article: Ahmad, A. B. @, Shamsuddin, C. M., Aziz, A. A., Alias, J., \& Mamat, A. (2018). The Principle of Interaction between Revelation and Mind under Islamic Perspective. International Journal of Academic Research in Business and Social Sciences, 8(10), 471-480.

Copyright: (C) 2018 The Author(s)

Published by Human Resource Management Academic Research Society (www.hrmars.com)

This article is published under the Creative Commons Attribution (CC BY 4.0) license. Anyone may reproduce, distribute, translate and create derivative works of this article (for both commercial and non-commercial purposes), subject to full attribution to the original publication and authors. The full terms of this license may be seen

at: http://creativecommons.org/licences/by/4.0/legalcode

Vol. 8, No. 10, 2018, Pg. 471 - 480

http://hrmars.com/index.php/pages/detail/IJARBSS

JOURNAL HOMEPAGE

Full Terms \& Conditions of access and use can be found at http://hrmars.com/index.php/pages/detail/publication-ethics 


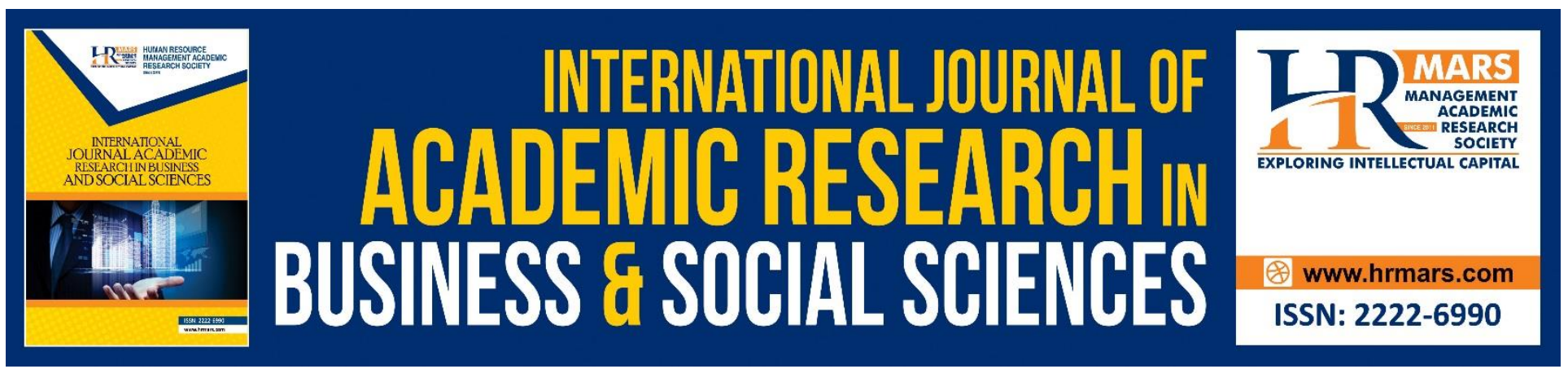

\title{
The Principle of Interaction between Revelation and Mind under Islamic Perspective
}

\section{${ }^{1}$ Aminudin Basir @ Ahmad, ${ }^{2}$ Chairozila Mohd Shamsuddin, ${ }^{3} \mathrm{Azwira}$ Abdul Aziz, ${ }^{4}$ Jamsari Alias, ${ }^{5}$ Akila Mamat}

Universiti Sultan Zainal Abidin (UniSZA), Kampus Gong Badak, 21300 Kuala Terengganu

Terengganu, Malaysia

Email: akila@unisza.edu.my

\begin{abstract}
Revelation is the fundamental source of Islamic teachings and it consists of two main areas; the Quran and al-Hadith. Both these sources describe the matters related to the teachings of Islam that consist of faith and syariah. The mind plays a role in understanding these two sources. There are explanations from the two sources that can be understood by the mind. In the meantime, there are also things that cannot be accepted by logic of the mind. This situation has caused conflict between revelation and the perception of common sense. The implication is that there are explanations of the revelation on matters of religion that are rejected by the mind. This is evidenced through the views of the Mutazilites, Jabariah, Qadariah, Shiites and others. This situation gives the impression as if the teachings of the revelation are contrary to the mind. Is it true that there is a conflict between revelation and the mind? Is it true that revelation is not compatible with the mind? This article explores the interaction between revelation and the mind. It also discusses the fundamentals of the method of interaction between revelation and the mind, if it occurs. Results have shown that in fact there is no conflict between revelation and the mind that could bring accusations against the weaknesses of the teachings of the revelation itself. The conflict that occurs is only from the external point of view without compromising the position of the glorious revelation. In addition, this article also presents methods to resolve potential future conflicts.
\end{abstract}

\footnotetext{
1 *Corresponding Author, Assoc. Proffessor,Dr. Pusat Citra Universiti, Universiti Kebangsaan Malaysia (UKM).Email: manhaj@ukm.edu.my.

${ }^{2}$ Senior Lecturer,Dr. Pusat Citra Universiti, Universiti Kebangsaan Malaysia (UKM).

${ }^{3}$ Senior Lecturer,Dr. Pusat Citra Universiti, Universiti Kebangsaan Malaysia (UKM)

${ }^{4}$ Senior Lecturer,Dr. Pusat Citra Universiti, Universiti Kebangsaan Malaysia (UKM) Email:jamsari@ukm.edu.my

5 Senior Lecturer, Faculty of Islamic Contemporary Studies, Universiti Sultan Zainal Abidin.
} 
INTERNATIONAL JOURNAL OF ACADEMIC RESEARCH IN BUSINESS AND SOCIAL SCIENCES

Vol. 8, No. 10, Oct. 2018, E-ISSN: 2222-6990 @ 2018 HRMARS

Keywords: Interaction, Revelation, Mind, Islamic Perspective

\section{INTRODUCTION}

The human mind created by Allah s.w.t is designed to understand the revealed doctrines which must comply with each of the clarification made by the revelation. In other words, there is no contradiction between a healthy mind with the revelation, namely the al-Qur'an and the authentic al-Sunnat that explain things of faith and the Islamic law. Instead, the interaction between them occurs harmoniously whereby the explanations of the revelation is relevant and acceptable to the nature of the human mind as created by Allah The Almighty.

If there is disagreement between the two of them, then it only occurs externally, but not in the actual truth, as is often experienced by the mujtahid in understanding the needs and position of specific texts. Allah's gift to mankind is that it is virtually impossible for Him to make the teachings of this religion contrary to the mind. Islamic teachings requires Muslims to understand the religion that Allah has revealed so that they may worship Him as commanded. If there is a conflict between the texts and the mind, how can a servant learn and understand His religion? From the perspective of Islam, the mind created by Allah s.w.t. has its own role and function.

\section{ISLAM VENERATING THE INTELLECT}

According to al-Rumiy, Islam reveres ('venerate' carries a different meaning) the intellect by encouraging the believers to think about their belief. Hence, Islam does not allow believers to simply accept whatever that is held by them. In fact, Islam requires the believers to think about the religion they profess. Thus, Islam places several signs in this matter. One of it is, Islam urges their believers to reflect and to ponder or tadabbur as Allah says:

Meaning: "(This is) a Book (the Qur'an) which We have sent down to you, full of blessings that they may ponder over its Verses, and that men of understanding may remember." (Chapter of Sad:29)

In relation to this verse, al-Syawkaniy (1983) clarifies that Allah s.w.t. revealed the al-Qur'an with the purpose so that its contents are to be examined and its meaning is thought of by the mind; it is not revealed merely to be read only without its contents observed. Meanwhile al-Qurtubiy (2006) stated that the verse explains of the obligation to understand the meanings of the contents of the alQur'an. This verse proves that the recitation of the al-Qur'an should be done in the proper manner (tartil), and it is better than reading it quickly (hazzi) because the examination of the contents of the al-Qur'an is not going to happen by reading it quickly. He also added that according to al- Hasan alBasriy, to ponder upon (tadabbur) the signs of the verses of the al-Qur'an is by following it.

The above explanation shows that Allah s.w.t. commanded that the contents of the al-Qur'an are observed and its meaning refined by the mind. Al-Qur'an is not solely revealed only to be read without examining the meaning contained within each of its verses. On the basis of thinking and observing the contents of these verses that Allah has given success to the Islamic scholars in their efforts to explore and deepen the knowledge contained therein. 


\section{ARGUMENT OF CONCEPT FORMATION \\ Evidences From the al-Qur'an.}

Among the evidences from the al-Qur'an for the formation of this concept are:

In the Chapter of al-Zukhruf, verses 1-3:

Meaning: "Ha-Mim (1) By the manifest Book (that makes things clear, i.e. this Qur'an) (2) We verily, have made it a Qur'an in Arabic, that you may be able to understand (its meanings and its admonitions) (3)."

Based on the above verse, Ibn Kathir (1981) explained that the al-Qur'an is clear and obvious in its meanings and utterances. This is because the al-Qur'an has been revealed in the Arabic language which is the most clear and profound language for communication amongst humans, and this is why Allah s.w.t. explained that He revealed the al-Qur'an in the Arabic language that is clear and unambiguous, so that humans understand and can ponder upon it (tadabbur). Furthermore, alR'aziy (2004) said that the above verse shows that once someone understands the content of alQuran together with its meaning, there will be no doubt in it.

From aforementioned statement, it clearly shows that the al-Qur'an which is the source of 'aq'idat and syari'at can be understood and accepted by the human mind. If the mind is contrary to the authoritative texts, Allah s.w.t will not command His servants to understand and ponder upon (tadabbur) its contents.

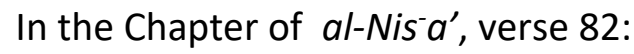

Meaning: "Do they not then consider the Qur'an carefully? Had it been from other than Allah, they would surely have found therein much contradiction."

Ibn Kathir (1981) clarified that Allah s.w.t. commanded his servants to ponder over (tadabbur) the al-Qur'an as well as prohibits them from staying away from it, forbids them from turning away from His teachings and also from understanding its clear contents. In this verse, Allah also explains that in the al-Qur'an there is no dispute as well as confusing mismatch and there is none contained in the contents which are mutually contradictory.

This is because the al-Qur'an was revealed by Allah s.w.t. the Most Wise, and Most Praiseworthy. Hence, al-Qur'an is true and it comes from Allah, the Most True (Ibn Kathir 1981). Meantime, according to al-Raziy (2004), amongst the specility of al-Qur'an is it will be preserved from having any distortion or change in its content. It is proven that the meaning of Quranic verses can be understood which ultimately rejects the allegation made by those who think that the content of alQur'an was solely known by Rasulullah p.b.u.h and Islamic leaders. He emphasized that the above 
INTERNATIONAL JOURNAL OF ACADEMIC RESEARCH IN BUSINESS AND SOCIAL SCIENCES

Vol. 8, No. 10, Oct. 2018, E-ISSN: 2222-6990 ㄷ 2018 HRMARS

verse obliges mankind to profoundly study the content of al-Qur'an and believe in it while at the same time forbade taqlid or to follow blindly without reason.

\section{Evidences From the al-Sunnah.}

The evidences from al-Sunnat are related to the abovementioned concept and are explained below:

Al-Bukhariy (1997) narrated with the sanad until it reaches Abu .Hurayrat r.a., the Prophet p.b.u.h. said:

Meaning: "Leave me (as I leave you) for the people who were before you were ruined because of their questions and their differences over their prophets. So, if I forbid you to do something, then keep away from it. And if I order you to do something, then do of it as much as you can."

The above hadith clearly shows that religious teachings which are in the form of commands and prohibitions can be understood by the mind. This is why the Prophet p.b.u.h. asserted that what comes from him which is connected to a ban should be avoided while those connected with an order must be done according to the level of capability. If the mind is contrary to the authoritative texts, hence the Prophet p.b.u.h. would not explain as such.

IbnAbi'Asim (2005) related with the sanad until it reached al-'Irba'd Ibn S'ariyat r.a., the Prophet p.b.u.h. said:

Meaning: "Verily I am as a light to you, whose leaving will render the day as dark as the night, those who deny the light will be forever lost".

The above hadith pointed out that Islamic teachings that contain 'aq-idat and syari'at can be clearly understood by the mind similar to the depiction of night as day which is referred to the Prophet p.b.u.h.

\section{Evidences From the al-Athar.}

As the evidence of al-Ath ar explains, the depiction of the concept above among them is narrated by Muslim with the sanad until it reached Salman al-Farisiy r.a., he said:

Meaning: "The polytheists remarked to us: "I see your companion (the Prophet p.b.u.h.) teaches you about everything, even about excrement. "Salman said: "Yes. Indeed, he has forbidden us that anyone amongst us should cleanse himself with his right hand" (al-Nawaw-iy 1994).

Al-Nawawiy (1994) explained that Salman meant that he has been taught all things desired by the Muslims in matters relating to religious affairs, including the ethics of cleansing (istinjak). The above statement clearly shows that all religious matters taught by the Prophet p.b.u.h. can be understood and accepted by the mind even the ethics of cleansing (istinjak). All the propositions mentioned above show that there are no contradiction or objection between a healthy mind towards al-Quran and al-Sunnah in things that are related to aqidah or syariah. Instead, the mind will be able 
INTERNATIONAL JOURNAL OF ACADEMIC RESEARCH IN BUSINESS AND SOCIAL SCIENCES Vol. 8, No. 10, Oct. 2018, E-ISSN: 2222-6990 ㄷ 2018 HRMARS

to accept and understand al-Quran verses that clearly explain those things. In order to understand this concept better, there are a few main principles in this concept as explicated below :

\section{THE KEY PRINCIPLES IN THE CONCEPT}

The following are explanations on some of the key principles contained in the concept being discussed.

\section{The Mind is Required to Submit and Obey the Texts of the al-Qur'an and al-Sunnat.}

This principle means that a healthy mind must submit and obey the evidences of the texts of the alQur'an and al-Sunnat in matters of aqidah and syariah. In other words, if there is apparently a common sense view that is contrary to the authoritative texts, hence the mind must be compliant and accept the evidences and explanations of the texts. There is absolutely no weakness in the text of Al-Quran, however the weakness is in man's mind, which have the limitation to understanding things.

In one event happened during the Treaty of Hudaibiyah al-.Hudaybiyyat. 'Umar Ibn al-Khatab did not agree with the content of that agreement which he thinks give more benefits to the opponent. Hence, he (Abu Bakr) expressed his disapproval about the agreement. However, . Ab-u Bakr asked him to stay loyal to Rasulullah p.b.u.h in that matter. Finally, he went and met Rasulullah himself to give his opinion. Prophet Muhammad then said:

Meaning:" "I am the servant of Allah (SWT) and His Messenger; I will never disobey His command, and He will never forsake me.."

Upon hearing that, 'Umar felt guilty for opposing things agreed by Rasulullah p.b.u.h (IbnKathir,1988).

In the event mentioned above, 'Umar disagreed with Rasulullah's decision to accept that agreement as he thinks it will give more disadvantages to the Muslims. However, Rasulullah p.b.u.h chose to accept it as it was a revelation that needs to be adhered to. It finally proves that the sign for revelation is truthful and exact. It finally gives great profit to Muslims. Hence, in relation to this discussion, it shows that when there is contradiction between the mind and revelation, then the mind needs to follow Allah's command and put it as priority. According to this principle, Abu Hurayrat narrated ,al-Lalika'iy (2004) heard Rasulullah p.b.u.h said:

Meaning: "People will keep on asking questions until someone will say, 'Allah created the universe, but who created Allah?' Whoever encounters anything like that, let him say, 'Amantu Billaah (I believe in Allah)."

According to IbnHajar (1986), those questions might be brought up due to two reasons, which are questions asked by human themselves and by the hesitation caused by the devil. She further said that if the question was asked by humans, it can be explained by giving a clear and strong argument. However, if it comes from the devil then we should seek help from Allah. 
The question brought up above will surely cause hesitation in humans' mind. Hence, in this situation, the mind should abide by the text of Al-Quran and al-sunnah without the need to question and agree that the mind has its limitation. Hence, the mind should be in the state of limitation which has been promoted by the syara' without the need to go beyond it. Abu Hurayrah said that the above shows the attitudes of a muslims when the questions about 'aq'idat is being raised. The same stand must be showed in syari'at matter. AbuDawud (2009) narrated with the sanad until it reaches 'Ali r.a, he said:

Meaning :" If the religion were according to opinion then the underside of the khuffayn would have been wiped, but I have seen the Messenger of Allah sallallahu 'alayhi wa sallam wiping over the upper part of the khuffayn"

The statement given by 'Ali r.a shows that khuf (shoes) rationally should be wiped on its underside because there is the place used to step and where the dirt is collected. However, Rasulullah P.B.U.H was asked to wipe on the upper part of the khuf since it is a command given by Allah as revealed to him. Based on this revelation, the mind would not be able to think of the benefit and wisdom behind those commands. This is because all the command is ta'bbud. 'Ali R.A in his speech said that the mind should abide by the Rasululllah's p.b.u.h command although it seems illogical to the common human mind.

Therefore, it can be construed that the mind has its limitations in understanding some things. It cannot rely solely on its own ability in understanding religion without depending on the explanation from revealed knowledge. According to the Syariah law, the mind should follow the explanation from revelation. However, this kind of loyalty is not possessed by the defiant group. al-Mu'tazilat for instance, denies the attributes of Allah and His noble qualities as they believe if Allah has that kind of attributes, He would have mass; if He had mass, He would be just like His creation. As the conclusion, they denied all attributes owned by Allah as well as His noble characteristics.

\section{Religion as the Basis of Guiding and Protecting the Mind from Misappropriation}

This principle explains that all matters relating to religion related to 'aq-idat and syar'i 'at that have been described by al-Qur'an and al-Sunnat can be accepted by the mind. In other words, the mind itself is guided by religion to allow it to accept religion itself. This principle is more focused on the meaning of commandment or referred to as Maqa.sid al-Syari'at.

According to al-Ghaz'aliy as mentioned by al-'Alim (1991), that the meaning of commandment was intended to bring benefits to humans for the concerns of the world and the hereafter, whether the advantage is obtained in the form of a benefit or in the rejection of a particular form of harm. In the context of Allah s.w.t as the obligator, Y-usuf. Hamid clarified that there are two meanings of the commandment itself, the first meaning refers to the purpose of the creation of beings, while the second meaning refers to the commandment of the religion itself to the being. For the first purpose, he explained, Allah created His creatures for the purpose so that they perform perfect obedience to Him or ubudiyyah without committing syirik or associating Him with something, as Allah s.w.t says in the Chapter of al-Dh-ariy-at, verse 56: 
INTERNATIONAL JOURNAL OF ACADEMIC RESEARCH IN BUSINESS AND SOCIAL SCIENCES

Vol. 8, No. 10, Oct. 2018, E-ISSN: 2222-6990 ㄷ 2018 HRMARS

Meaning: "And I did not create Jinn and mankind except that they may worship Me."

On this basis too, the prophets and the Apostles were sent by Allah s.w.t. where their task is to invite people to the Oneness of Allah (tauhid) and stay away from any form of syirik; in this regard Allah says in the Chapter of al-Na.hl, verse 36:

Meaning: "And verily We sent messengers to every nation (proclaiming) "Worship Allah (alone) and avoid Th-aghut."

All the outcome and results from the worship performed will be enjoyed and felt by the creature itself. Meanwhile for the second meaning, namely the commandment of the religion itself, he clarified that it is intended to achieve the first purpose which is to obtain good for the servant himself in this world and the hereafter. With the establishment of syar i'at, it will be able to organize and arrange their lives so as to obtain happiness and perfection of life.

Yusuf (1991) further contends that Islamic teachings will continue to give guidance, justice, mercy and kindness. Islam aims to facilitate and not to trouble nor burden human beings. Thus, Islam places some key principles for the purpose that humans can live their lives well, such as the principles of easing the burden (Raf'u al-.Haraj), rejecting harm (Daf'u al-Darar), the principles of justice, determining the rights, the principles of trust and so on.

Hence, in this case, the commandment is intended to preserve the five fundamentals or basics, namely, religion, life, mind, lineage and property Al-Syatibiy (1999) mentioned these five things as al-Kulliyy at al-Khamsat which is considered as the basis for the meaning of commandment, where the goal of the Islamic law or syar'i'at itself is to preserve these five things. Therefore, one of the five things that is the focus of the commandment is to protect the mind from any form of misappropriation and guide it so that it is on the right track as required by Allah s.w.t. In this case, there are two main things to nurture and protect the mind from misappropriation; the first thing is related to the commands of the religion to seek knowledge, the second is related to the prohibition of being caught up in things that can harm the mind. Relating to the first matter, there are many texts from al-Qur'an and al-Sunnat that explains the obligation to seek knowledge and the gains promised in return, including obtaining the reward of heaven. Upon explaining the obligation of seeking knowledge for instance, Ibn 'Abd al-Bar (1994) has included many hadith with its chain of narration (sanad); among them is the had-ith from Anas Ibn Malik r.a., the Prophet p.b.u.h. said:

Meaning : "Seeking knowledge is obligatory on every Muslim"

IbnQayyim (1984) conveys that the position of the highest knowledge is to learn the Book of Allah s.w.t and the Sunnah of the Prophet p.b.u.h. As such, the human mind must be exerted with knowledge derived from the al-Qur'an and al-Sunnat. In this way, the mind would be protected from any misappropriation. There is no doubt that when Islam obligates the seeking of knowledge, especially those of personal obligation or fardh 'ain, it shows the importance of knowledge in 
providing happiness in this world and hereafter. In fact, knowledge itself is a heritage of the prophets and apostles such that the efforts to learn the teachings of the religion are a huge virtue in the sight of Allah that is bestowed upon His servants.

Meanwhile from the angle of the second matter, Islam protects the human mind by commanding humans to stay away from all kinds of vice and sin whether the sins are those that are unforgiven by Allah such as syirik, the big sins such as gambling, drinking alcohol and the light or the minor sins. This is because all kinds of sins and vices can deviate the mind from being guided on the right path.

Subsequently, IbnQayyim (1990) added that vice will cause humiliation to a servant, in which the honour of the servant is on his obedience to Allah. He further clarified that vice can also damage the mind; this is because the mind is likened to light, while vice will extinguish the light of the mind; hence when the lights are extinguished, the mind will be weak. The effects of vice on the mind will also cause one's opinion towards something to become so weak and far from the truth in comparison to those who stay away from vice in which his view is more accomplished and truthful.

From the description set forth above, it clearly illustrates that for the mind to receive the teachings related to 'aq-idat and syar ${ }^{-}$'at, then the mind has to be guided by religion itself. As such, the mind is one of the five things that are given important attention by the religion. This is to ensure that the mind will always be on the right path as required.

\section{CONCLUSION}

Based on the overall discussion presented in connection with this concept, it clearly shows that there is no contradiction between the mind with the al-Qur'-an and al-Sunnat in understanding the matters of 'aq-idat and syari'at. In fact, this proves that the mind has a close association to the texts, and can embrace all the explanations advanced by the al-Qur'an and al-Sunnat in the matters of 'aq'idat and syar'i'at.

\section{REFERENCES}

Al-'Alim, Y.H. (1991). Al-Maq'a.sid al-'-Ammat li al-Syar'i'at al-Islamiyyat. Herndon, US: al-Ma'had al-"'Alam-iy li al-Fikr al-Isl'am-iy.

Ibn 'Abd al-Bar, A.U.Y. (n.d.). J'ami' Bayan al-'Ilm wa Fadlih. Beirut:Darar al-Kutub al-'Ilmiyyat. Ibn Abi 'A.sim, A.B.A. (1985). Kit'ab Al-Sunnat. reedited by Mu.hammad N'asir al-D'in Beirut: AlMaktab al-Isl'am-iy.

al-'A.sqalaniy, I.H. (1986). Fath al-Bar-iy bi Syarh Sahih al-Bukhariy. Kaherah: Dar al-Diyan Li alTurath.

IbnKathir, I.U. (1988). Al-Bidayah wa al-Nihayah. Beirut: Dar al-Diyan

IbnKathir, I.U. (1981). Tafs'ir al-Qur'an al-'Az'im. Beirut: D'ar al-Fikr.

Ibn Qayyim, S. (1990). Al-Jawab al-Ka-iy Liman Sa'ala 'An al-Dawa' al-Sya-iy. reedited by Sa'id Muhammad al-Liham. Beirut: Dar I.hya' al-'Ulum.

Ibn Qayyim, S. (1984) al-Fawaid. Beirut: Dar al-Nafa'is 
INTERNATIONAL JOURNAL OF ACADEMIC RESEARCH IN BUSINESS AND SOCIAL SCIENCES

Vol. 8, No. 10, Oct. 2018, E-ISSN: 2222-6990 @ 2018 HRMARS

Al-Lalika'iy, Ab-H. (2004). Syar.h U.s'ul Ik'tiqaad Ahl al-Sunnat wa al-Jama'a'at. Reedited by Sayyid 'Imran. Kaherah: Dar al-Hadith.

Al-Nawawiy (1994). Syra.h .Sa.h-i.h Muslim. T.tp: Muassasat Qur.tubat.

Al-Rumiy, F.R. (1987). Manhaj al-Madrasat al-'Aqliyyat al-.Hadhitiyyat fi al-Tafs'ir. Beirut: Muassasat al-Ris`alat.

Al-Sya tibiy, M. (1999) . Al-Muwafaqat. Al-Azhar: Maktabat Sab-i Mu hammad al-Wak-il. Beirut: Dar al-Makrifah.

Al-Syawkaniy, M.A. (1983). Fat.h al-Qad-ir. Beirut: D־ar al-Fikr.

Al-Qurtbiy, M.A.A. (2006). Al-Jami' li Ahkam al-Quran. Beirut:Muassasah al-Risalah.

Al-Raziy, M.U. (2004). Al-Tafsir al-Kabir Beirut: Dar al-Kutub al-Ilmiyyah.

Al-Bukhariy, M.I. (1997). Sahih al-Bukhariy.. Riyad: Dar al-Salam.

IbnAbi'Asim, A.A. (2005). Al-Sunnah. Riyad: Dar al-Sumai'iy.

AbuDawud, A.A. (2009). Sunan Abi Dawud. Beirut: Dar al-Risalah al-'Alamiyyah.

IbnAbdal-Bar, Y.A (1994 ). Jami Bayan al-'Ilm wa Fadlih Damam: Dar ibn Al-Jawziy. 